\title{
Clio
}

Women, Gender, History

$40 \mid 2014$

Making Gender with Things

\section{Women at Qumrân? Between texts and objects}

Des femmes à Qumrân? Entre textes et objets

\section{Katharina Galor}

Translator. Ethan Rundell

\section{OpenEdition}

\section{Journals}

Electronic version

URL: http://journals.openedition.org/cliowgh/600

DOI: $10.4000 /$ cliowgh.600

ISSN: 2554-3822

Publisher

Belin

Electronic reference

Katharina Galor, "Women at Qumrân? Between texts and objects », Clio [Online], 40 | 2014, Online since 15 April 2015, connection on 20 April 2019. URL : http://journals.openedition.org/cliowgh/600 ; DOI : 10.4000/cliowgh.600 


\title{
Women at Qumrân? Between texts and objects
}

\author{
Katharina GALOR*
}

Comparison of the Dead Sea scrolls with other material from the site of Qumrân and the surrounding area has given rise to diverse and contradictory theories, hypotheses and reconstructions. The issue of gender occupies a central place in them and can shed light on the mystery surrounding the community that is said to have copied or deposited the cave manuscripts while inhabiting (according to the traditional interpretation) the buildings situated on the Qumrân plateau. The role of women in the community described in the manuscripts, their status in the society mentioned in the literature of the first century CE, and the presence or absence of material evidence as to their presence at Qumrân and in the surrounding area have given rise to much learned scholarly analysis and commentary. The present article seeks to establish some order in the chaos of contradictory and problematical assumptions and theories, while distinguishing between texts and material finds, facts and hypotheses. Above all, it aims to lay the groundwork for a fruitful dialogue between written sources and archaeological remains.

\section{Excavation, investigation and interpretation: an exclusively masculine terrain?}

Father Roland de Vaux of the École biblique et archéologique française of Jerusalem (EBAF), director of excavations at Qumrân between 1951 and 1956, is often cited as the source of the traditional interpretation of the site, which he based on his reading of the so-

I would like to thank Jean-Michel de Tarragon, Jean-Baptiste Humbert and Kathie Tchobroutsky for their commentaries and corrections regarding my manuscript. 
called community (or "sectarian") scrolls. According to de Vaux, the complex, as well as other associated buildings and artifacts, served as a community center for a male celibate religious community. He is certainly not the only scholar responsible for this interpretation which - although he was conscientious and scientific - springs in large measure from his own personal impression.

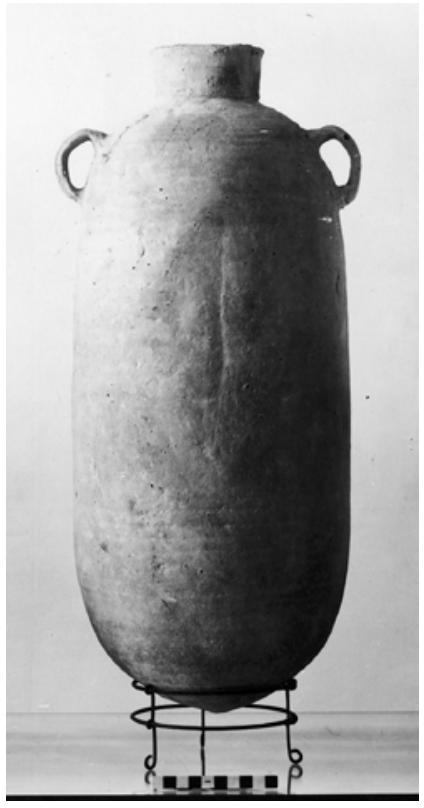

Fig. 1. A jar that held manuscripts. Photo Palestine Archaeological Museum (C) École biblique et archéologique française.

It is generally acknowledged that the first leather scrolls, wrapped in linen and stored in large jars (fig. 1), were discovered in 1947 in a cave located a little more than a kilometer from the site. According to John C. Trever, a young scholar at the American School of Oriental Research in Jerusalem, the scrolls were accidentally discovered by a Bedouin shepherd, Muhammed edhDhib Hassan, as he searched for one of his lost goats. From there, the scrolls apparently passed through the hands of numerous merchants, the first of whom was from Bethlehem, a certain Ibrahim 'Ijha, who is said to have brought them to one or more antiquities dealers: Faidi Salahi or Faidi al-'Alami (perhaps one and the same individual known under two different names) as well as, apparently, Khalil Iskander Shahin, better known as Kando. ${ }^{2}$

1 The Dead Sea scrolls are generally divided between three groups: biblical texts, "communitarian" texts and "non-communitarian" texts. The "communitarian" texts use a terminology and ideas that show that they were produced by an organized milieu, with religious practices and ideas that explain why we sometimes use the term "sectarian", frequently used in English; see Paul 2008: IX-XVI.

2 There have been many versions of the scrolls' discovery - for example, the rather popular version offered in VanderKam \& Flint 2002: 3-19. 
In 1948, Eléazar Sukenik was the first scholar to draw a link between the community mentioned in the manuscripts and the Essenes, a Jewish dissident community described by such firstcentury CE historians as Philo of Alexandria, Pliny the Elder and, above all, Flavius Josephus. The major significance of the scrolls' discovery, which was very rapidly made public, encouraged Bedouins and archaeologists - all of them, no doubt, men - to systematically explore the natural and artificial caves of the Dead Sea region. Where the former were driven by the prospect of financial gain, the latter were motivated by scientific curiosity or a sense of adventure. Between 1947 and 1956, their unremitting work led to the discovery of eleven caves containing thousands of manuscripts in an often fragmentary state, a discovery that completely revolutionized the study of the Hebrew bible and our knowledge regarding the shared origins of the two Abrahamic religions.

Alongside Father Vaux himself, the international team of editors that he brought together for the publication of the cave manuscripts included: Father Pierre Benoit, Father Dominique Barthélemy and the priests Jozef Milik and Jean Starcky, representing France; Frank Moore Cross and Mgr Patrick W. Skehan, representing the United States; John M. Allegro and John Strugnell, representing Great Britain; and Claus-Hunno Hunzinger, representing Germany. A large portion of the first seven scrolls discovered by the Bedouin shepherd were published by a father-son pair of Israeli archeologists, Eléazar Sukenik and Yigal Yadin. Since 1991, Emanuel Tov has overseen the editorial team. Much ink has been spilt over these scholars' national and religious origins. For example, the identification of Qumrân as a center reserved for the religious, ritual and intellectual practices of the community that supposedly produced these writings has been criticized on the grounds that Roland de Vaux was unduly influenced by his own celibate and monastic life at the École biblique et archéologique française. Many scholars have underscored the dubious nature of his terminology, as well as his use of the terms scriptorium (fig. 2) and refectorium (fig. 3) to describe certain architectural spaces. ${ }^{3}$ Up till now, however, nothing has been said about the fact that all of

3 Magness 2002: 15-16. 
the scholars involved in the first two decades of research on Qumrân were men, or the possible consequences of this fact.

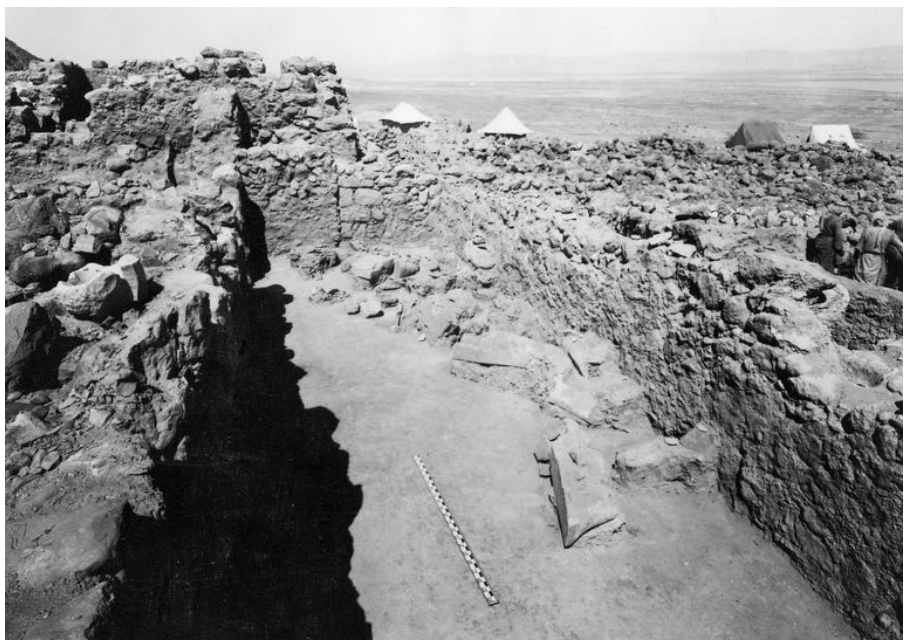

Fig. 2. The «scriptorium » (locus 30).

Photo PAM (C) École biblique et archéologique française.

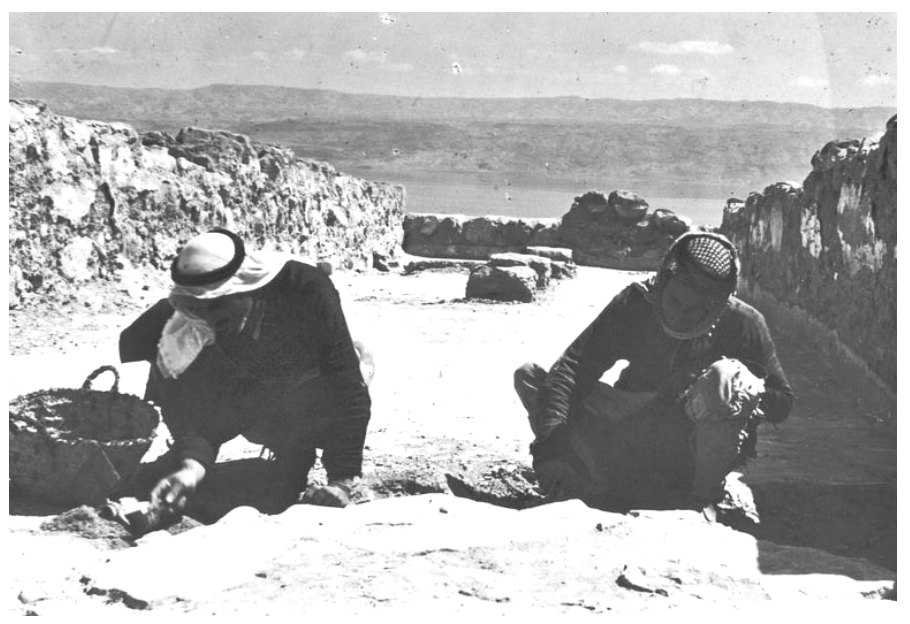

Fig. 3. The « refectorium 》 (locus 77).

Photo by de Vaux (C) École biblique et archéologique française. 
The dominant role played by male experts in the interpretation of Qumrân and the Dead Sea scrolls is typical of what is known as biblical archaeology as it was practiced until the 1960s, particularly with regard to fieldwork. It was not until the 1970-80s that women archaeologists began to occupy important positions within the Israeli Department of Antiquities and Museums (since 1990 known as the Israel Antiquities Authority) and in university departments. And it was not until the early 1980s that women researchers became active in interpreting the scrolls and the site. These women researchers included historians, biblical scholars, epigraphers, archaeologists, anthropologists and curators. ${ }^{4}$ While Israeli women became heavily involved in archaeology earlier than their counterparts in other countries, there is ample evidence that they were discriminated against relative to their male colleagues. Until the 1990s, in any case, the sex of the scholar was of little importance: so convinced was everyone that women were absent from the Qumrân community that no attention was paid to the many references to them to be found in some of the manuscripts or the ambiguities relating to the use of the objects found in the excavations.

With the celebration of the hundredth anniversary of the École biblique in 1989, and the resumption of work on archaeological material under the leadership of Jean-Baptiste Humbert, new questions arose regarding the presence of women. ${ }^{5}$ From that time on, the question of the role of women in the communities and, more generally, in Judean society during the Second Temple period has occupied an increasingly important place in research on Qumrân and the Dead Sea scrolls. ${ }^{6}$ Yet, despite the attention given to the question of whether women were present at Qumrân, the intrinsic value of the

4 Those most often cited in this connection are Eileen Schuller, Pauline DonceelVoûte, Linda Bennett Elder, Lena Cansdale, Joan Taylor, Jodi Magness, Devorah Dimant, Orit Shamir, Susan Sheridan, Mireille Bélis, Sidnie White Crawford, Maxine Grossman and Tal Ilan.

5 Two volumes of excavation reports have been published so far: Humbert \& Chambon 1994; Humbert \& Gunneweg 2003.

6 In recent years, the issue of gender has been addressed by most conferences regarding the Dead Sea scrolls. Often, an entire session is devoted to it. See for example Roitman et al. 2011. 
material culture of the site has not been fully recognized. This neglect reflects a certain limitation on the part of archeologists who have paid insufficient attention to gender. Of all the disciplines within the human sciences, archaeology was the latest to open up to gender analysis. ${ }^{7}$ In France, the first publication regarding material culture and the social production of sexed identities has only just appeared, thirty years later than the first studies published in the United States. ${ }^{8}$ Compared to the research that has been carried out in many countries of the Mediterranean basin and the Middle East, the delay is even more pronounced in the case of Palestine. This may at least be partly explained by the fact that archaeology in the Holy Land is overshadowed by the place accorded to the Bible in the reconstruction of the past. ${ }^{9}$ The same holds for the archaeology of Qumrân relative to the Dead Sea scrolls. While it is impossible to evaluate this site without taking into consideration contemporary texts associated with the region, the subjective dimension - whether imaginary or ideological - that these texts project upon the site is too often ignored.

Given what the textual and material data tells us, dialogue between the disciplines - and the existence or absence of communication between them - is today doubtless more important than the sex of the scholar. Even though experts on the scrolls generally make reference to archaeological discoveries, and archaeologists and archaeo-anthropologists keep up to date with the various theories prevailing among philologists, few of them genuinely master the methodologies of the other disciplines or are capable of independently evaluating the accuracy of all data. We are far from the time of Vaux, Sukenik or Yadin, whose expertise encompassed both philological analysis and the study of archaeological material. The growing numbers of specialists within both fields has created an enormous chasm, rendering the communication of ideas and data ever more difficult. This tendency is clearly in evidence in Crawford's recent study, which concludes that the presence of women within the

\footnotetext{
7 Meyers 2003: 185.

8 Whitehouse 2006; Anstett \& Gélard 2012.

9 Meyers 2003: 187.
} 
community - henceforth an established fact, in her view - does not concur with the material culture of the Qumrân site. ${ }^{10}$ Faithful to de Vaux's impressions, her summary review of the archaeological and anthropological remains is unfortunately not up to par with her textual analysis. If we could combine the mastery of the textual and material sources displayed by mid-twentieth-century scholars with the interest in women and gender to be found among a number of their late-twentieth and early-twenty-first century counterparts, of both sexes, we would end up with a much stronger interpretation than those that presently prevail.

\section{The traditional interpretation}

Since the discovery of the Dead Sea scrolls, archaeology has played an important role in the identification of the Qumrân site, the reconstruction of the buildings, the analysis of artefacts and theories about the site's inhabitants. Until now, the dominant interpretation was that offered by Roland de Vaux, who considered the data from the manuscripts, the literature of the first century $\mathrm{CE}$, and the archaeological discoveries as seemlessly fitting together. ${ }^{11}$ Sometimes referred to as "consensual theory", this synthesis of the data identified the manuscripts' authors as Essenes, a religious group that used Qumrân as a center for communal life and a religious meetingplace between $130 \mathrm{BCE}$ and $68 \mathrm{CE}$. De Vaux reconstructed their philosophy and way of life on the basis of a selective reading of manuscripts - in particular, the Manual of Discipline and the Damascus Document, which were juxtaposed with passages from such firstcentury authors as Philo, Pliny the Elder and Josephus. De Vaux played down the divergences and often actual contradictions found in these sources, in order to suggest that the Essenes led a life of religious celibacy at Qumrân, leaving tangible traces of this at the site.

According to de Vaux, the Essenes were a marginal group with beliefs and practices different from those of the Jews, for whom worship, as well as religious and political governance were centered in

\footnotetext{
10 Crawford 2003: 141-142.

11 De Vaux 1961 [1973 for the English translation].
} 
Jerusalem around the Temple and the priestly hierarchy. This community of ascetics is said to have lived in complete economic and social independence from the rest of society. The buildings excavated on the Qumrân plateau (fig. 4) supposedly provided a place for communal activities such as subsistence industry, meals, gatherings, prayer, ritual bathing, as well as scribal and study activities. For de Vaux, the lack of space devoted to everyday domestic purposes suggested that the Essenes slept in caves and tents in proximity to the architectural complex. The necropolis, separated from the buildings by a long wall and consisting of around 1200 tombs (fig. 5), was said to have also retained traces of a community of celibate men. The supposedly indisputable architectural evidence for this theory included the site's isolation, its unique architectural character and, finally, the unusual pottery found only at the site itself and in the caves containing the scrolls. Despite advances in the study of the manuscripts and archaeological material, this interpretation was recently adopted with only minor modifications by Jodi Magness, an American archaeologist: she has succeeded in consolidating and almost enshrining this theory among specialists of the manuscripts. ${ }^{12}$ Nevertheless, these days, fewer and fewer archaeologists subscribe to this traditional interpretation.

\section{Alternative voices demonstrating the presence of women}

For about forty years, the Manual of Discipline was the only published manuscript describing what is known as the Qumrân community. This text never mentions women and therefore sits well with the traditional interpretation. Yet the issue of Essene celibacy arose several years before the end of the manuscripts' publication in 1997.

12 Magness 2002. 


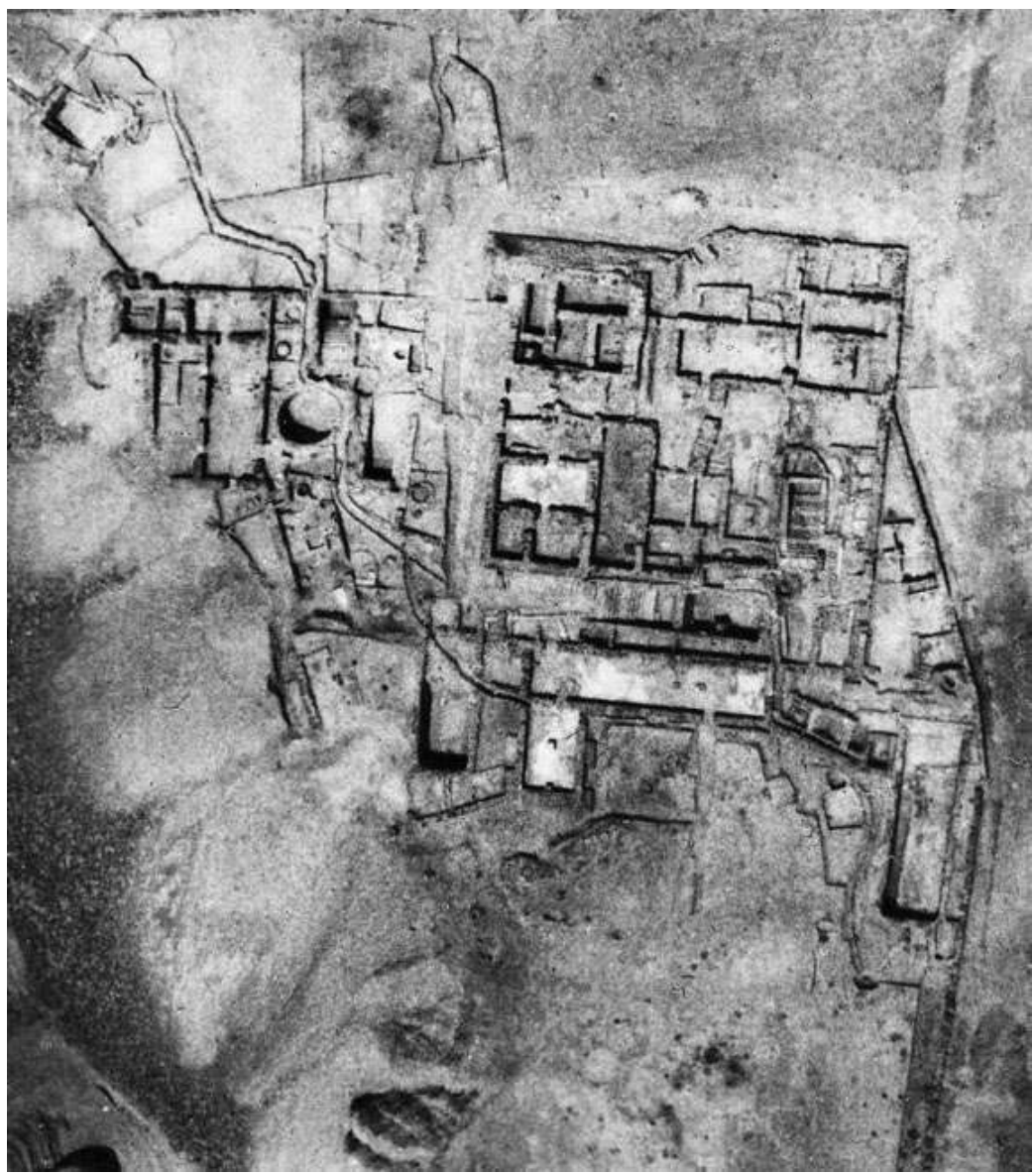

Fig. 4. Aerial view of the Qumrân architectural complex. Photo PAM (C) École biblique et archéologique française. 


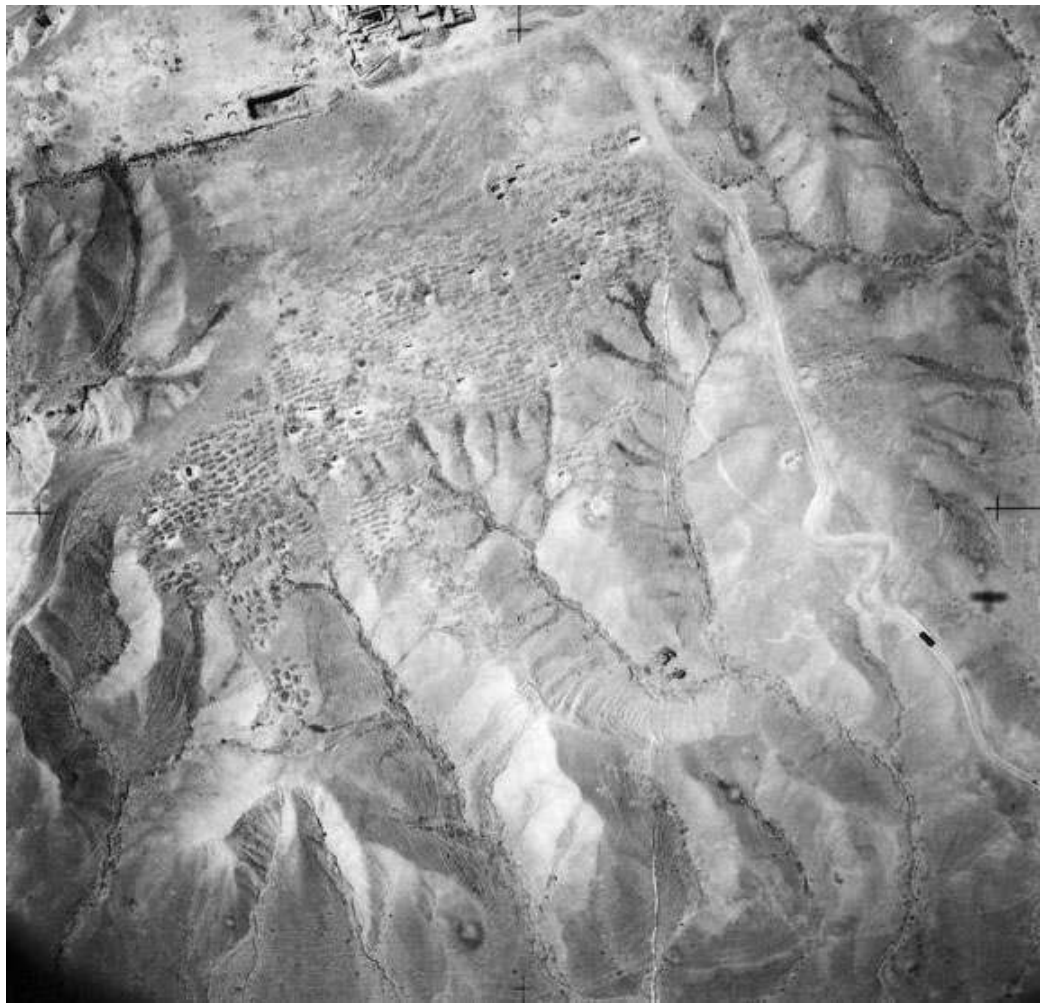

Fig. 5. Aerial view of the cemetery.

Photo PAM (C) École biblique et archéologique française.

In his description of the Essenes, the first-century CE author Josephus drew a sharp distinction between men who led a life of celibacy and those who married and had children. The identification of the authors of the Dead Sea manuscripts - members of a community they referred to as yahad - with the Essenes described by other first century historians has led several scholars to question an exclusively male yahad community. Despite these textual contradictions as to the identity of the manuscripts' authors, and the percentage of individuals who practiced celibacy, no one today 
doubts that women may were present in certain religious communities of the time. The many texts discussing women's legal status, rights and duties, issues of marriage and sexuality, as well as ritual practices are now included in the specialist documentary corpus. Moreover, it is today acknowledged that the literature of the time of the Second Temple was particularly androcentric - that is, written (composed, edited and copied) by men for an exclusively male public. As a consequence, the complete lack of reference to women is no longer considered proof of their absence.

Similar - indeed, perhaps even more marked - arguments have divided archaeologists. ${ }^{13}$ Alternative interpretations, whether or not influenced by new readings of the manuscripts, are essentially determined by the dynamic nature of recent explorations in this region: the reexamination of archaeological finds originally excavated by de Vaux, new excavations and surveys on the Qumrân plateau, and the discovery of many contemporary sites in the Dead Sea region. Though an advocate of the idea that the Qumrân site had been frequented by Essenes, Jean-Baptiste Humbert was the first to remark upon the resemblance between its architectural nucleus and the other Hellenistic mansions in the region. ${ }^{14}$ He noted the elaborate character of the architectural features which contrasted with the simplicity underscored in Roland de Vaux' excavation report. This architectural resemblance led Pauline Donceel-Voûte to propose that the buildings represented the remains of a Roman villa and had never served as a place of worship. ${ }^{15}$ Studying pottery, stone- and glassware together with her husband, Robert Donceel, strengthened her conviction that the buildings' inhabitants were not poor, humble people but rather landowners who enjoyed the luxury and comfort characteristic of so many other contemporary villas. ${ }^{16}$ According to Norman Golb and Robert Cargill, the site had been a fortress, whereas Alan Crown and Lena Cansdale see it as a commercial site or

13 The first colloquium to focus exclusively on the archaeology of Qumrân was held in 2002. Galor, Humbert \& Zangenberg 2006.

14 Humbert 1994.

15 Donceel-Voûte 1994.

16 Donceel 1999/2000. 
"entrepots". ${ }^{17}$ Systematic comparison with other Hellenistic and Roman period sites led Yizhar Hirschfeld to conclude that Qumrân had been a manor, once again underscoring the characteristics of the architectural complex, which were common at the time. ${ }^{18}$ Finally, according to Yitzhak Magen and Yuval Peleg, directors of excavations between 1993 and 2003, the site was used for the industrial production of pottery. ${ }^{19}$ In short, archaeologists are far from being in agreement as to the function of the Qumrân site. But what really matters here is that these interpretations no longer suffer from the isolation that characterized the excavations of the 1950s. The evaluation of the archaeological material now benefits from a comparative and regional perspective that allows one to distinguish traits specific to Qumrân from traits it shares with other sites of the same era. This leaves us with the question of the relationship between the site and the scrolls.

Karl Heinrich Rengstorf was the first to doubt that the site's inhabitants played any role in producing the manuscripts or had, faced with the threat of Roman invasion, subsequently hidden them in caves. ${ }^{20}$ In his view, the scrolls came from the library of the Temple of Jerusalem. More recently, Golb has defended the claim that the manuscripts were not written at Qumrân but rather originated in several Jerusalem libraries representing various currents of Judaism. ${ }^{21}$ The archaeologists Hirschfeld, Magen and Peleg have also rejected any direct link between the site's inhabitants and the cave scrolls. Whatever the case - and while we wait for new discoveries to confirm or invalidate these various theories - the discovery and publication of results from many other sites excavated in the region means that the architectural complex at Qumrân and the objects associated with it have lost their singularity. An interpretation of the site as a place where women might have lived has become both conceivable and plausible.

\footnotetext{
17 Golb 1995; Cargill 2009; Crown \& Cansdale 1994.

18 Hirschfeld 2004.

19 Magen \& Peleg 2007.

20 Rengstorf 1960.

21 Golb 1995.
} 


\section{Material culture and the social production of gender: the necropolis and some artifacts}

To better appreciate how and to what degree the archaeological material of Qumrân might elucidate questions concerning the sex of the individuals who inhabited this space, I propose to study the necropolis as well as some specific artifacts. This is no simple task: most archaeological discoveries are completely neutral from the point of view of gender, and only allow us to draw limited conclusions as to the identity of the individuals who produced or used them. ${ }^{22}$ This very ambiguity casts light on the impossibility of characterizing the Qumrân site as an exclusively male space. But the information supplied by the material culture is not exclusively negative in nature: tombs, a hair net, textile fragments and perfume containers supply invaluable clues, opening the way for other interpretations.

The Qumrân necropolis is located about 35 meters east of the architectural complex. Despite having excavated only forty of them (Figs 6 and 7), de Vaux claimed that the burials are confirmation that the site was used by a community of celibate men. Yet neither he 23 nor his colleague, Solomon H. Steckoll, ${ }^{24}$ who was specifically responsible for analysing the skeletons found there, produced an official study of them. After an interval of more than thirty years, this area of the site has once again drawn the attention of researchers, who have carried out more scientific and detailed analyses of the material found there. A little more than half of the bones were sent to Germany for study. ${ }^{25}$ The rest were distributed between two French institutions, the Musée de l'Homme in Paris and the École biblique de Jérusalem. ${ }^{26}$

22 A distinction must be made between sex and gender, qualifications that determine the results of the anthropological study carried out by Sheridan. This distinction is made in Sheridan, Ullinger \& Ramp 2003: 143-150.

23 De Vaux 1961: 37-39, 46-47 and 1973: 45-48, 57-58.

24 Steckoll 1968, 1969.

25 Röhrer-Ertl 2006; Rohrhirsch \& Röhrer-Ertl 2001.

26 Sheridan, Ullinger \& Ramp 2003. 


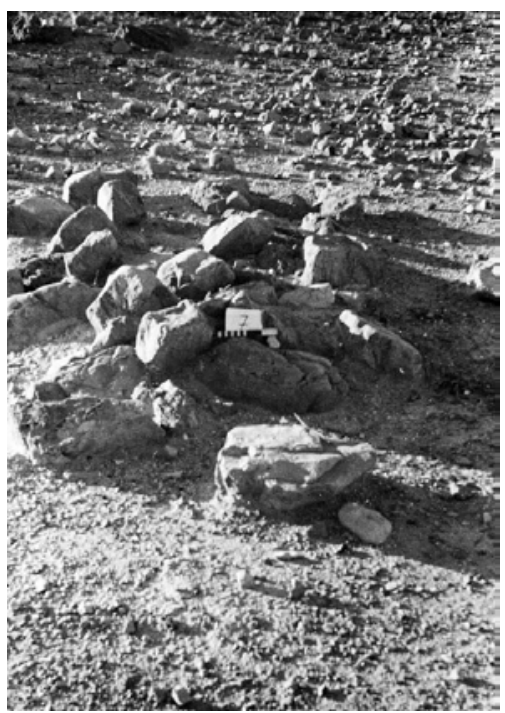

Fig. 6. Tomb 7 prior to being opened. Photo de Vaux (C) École biblique et archéologique française.
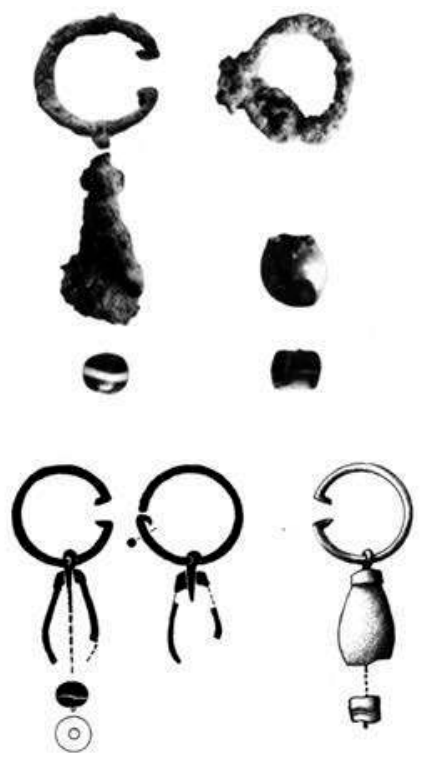

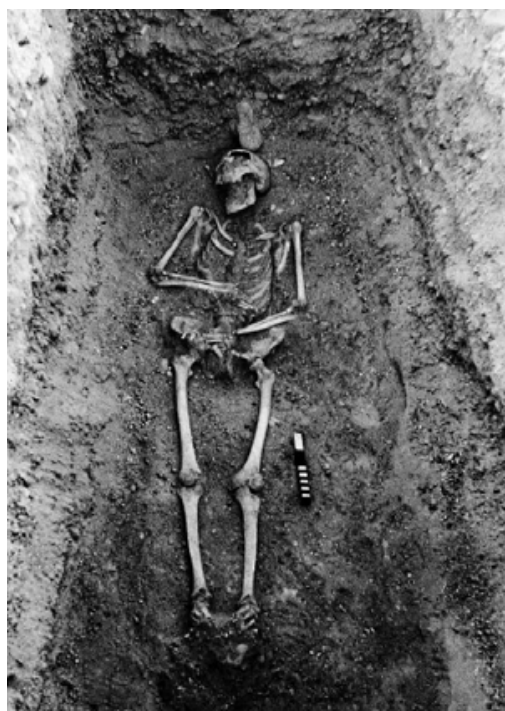

Fig. 7. Tomb 7 after being opened. Photo de Vaux (C) École biblique et archéologique française.
Fig. 8. Jewelry from Tomb 33. Photo de Vaux (C) École biblique et archéologique française. 
The necropolis was also more thoroughly explored in an effort to clarify the exact location, distribution and orientation of the graves. ${ }^{27}$

The state of preservation of the archaeological material and of the site itself does not allow definitive conclusions to be drawn, but their study nevertheless opens up perspectives differing from those supplied by the traditional interpretation. The only objects indicative of the sex of individuals are several pieces of jewelry found alongside women's bones (fig. 8). In keeping with the theory of male celibacy - that of Roland de Vaux - archaeo-anthropologist Joe Zias argues that the nature of the jewelry and the characteristics of the skeletons show that the tombs holding women's remains in Qumrân are of recent date and belong to a Bedouin community. ${ }^{28}$ Their location at the margins of the main cemetery supposedly confirms this chronological gap, an observation already made by de Vaux himself. In her detailed study of the funerary finds, Christa Clamer recently proposed that the ring, earrings and beads found in the abovementioned tombs should instead be dated to the Roman and Byzantine period, a claim I was able to confirm, except in regards to the bone and glass beads. ${ }^{29}$ The latter's typology has not sufficiently evolved to allow one to distinguish between beads dating from the Bronze Age and those dating from the late Islamic period. ${ }^{30}$ Unfortunately, the lack of pottery shards and other finds does not allow us to date these tombs more precisely.

The results are thus ambiguous but, whatever the case, they do not confirm the theory according to which the place was uniquely inhabited by men. Despite the progress of research, our knowledge regarding the individuals buried in the necropolis remains rather limited. The amount of time that elapsed between the discovery of the bones and their scientific study considerably reduces the probability of achieving valid results. The present state of the bones is appalling, and only allows a small amount of approximate data to be collected. Since

27 Hirschfeld 2004: 159; Rosenberg \& Meyers in Sheridan, Ullinger \& Ramp 2003: 135; Eshel et al. 2002: 138.

28 Zias 2000: 225-234.

29 Clamer 1997: 171-183.

30 Galor 2010: 395. 
only five percent of the tombs have been excavated, what's more, our statistical findings are very limited. Another difficulty stems from the fact that very few of the artifacts found in the tombs were documented, reducing the chronological, socio-economic and religio-cultural information available to us. Without revisiting the anthropological and archeological details concerning the tombs or reiterating the points of disagreement, I would like to underscore a few facts that are today acknowledged by most scholars. All of the tombs that have been excavated and studied date from the late Hellenistic and Roman periods, and are therefore contemporaneous with the plateau's architectural complex at the time of its maximum extension. Though it seemed unique to de Vaux, the Qumrân necropolis is now known to be of a type that was widespread in the region of the Dead Sea and, more generally, Palestine. ${ }^{31}$ The bones found in the graves do not allow us to draw any conclusions regarding the religious and ethnic identity of the individuals buried there, much less assign them to a particular community. ${ }^{32}$ Statistically, $23 \%$ of the bones belonged to women (with $63 \%$ belonging to men and $6 \%$ to children), a proportion similar to that observed at other sites in the region. ${ }^{33}$ Contrary to initial observations, the women's tombs do not appear to have a particularly concentrated or marginalized location. Finally, as far as objects indicating a particular sex are concerned, we are limited to a few pieces of jewelry, something generally associated with women. In short, arguments for male celibacy and Essene particularities are difficult to defend.

Beyond the necropolis, a few objects that shed light on the question of women's presence have been found in the buildings located on the plateau as well as in several caves. One of the difficulties involved in evaluating this material stems from the relationship between the Qumrân site and the caves. According to proponents of the traditional theory, these places were used by one and the same community - an argument based, among other things, on the unified material culture. However this link has been called into

\footnotetext{
31 Politis 2006.

32 Zangenberg 2000: 51, 66-72; Avni 2009.

33 Norton 2003: 123.
} 
question by an ever-growing number of researchers whose critical stance encourages them to differentiate between the objects found in the buildings and those originating in the caves. It should be noted that, in comparison with the caves, far fewer artifacts made from organic material have survived in the architectural complex. The differing conditions of conservation between the two contexts are particularly problematical for those who do not believe that the inhabitants of the site were directly linked to the caves.

One artifact almost totally neglected by the literature, but nevertheless bearing upon the identity of the inhabitants of Qumrân and neighboring sites, consists of a hairnet found in one of the caves. The oldest representations of hairnets appear on prehistoric figurines. ${ }^{34}$ A luxurious version made of gold thread, dating from the late Hellenistic and Roman period existed: an excellent example of this can be found in the famous Pompeii fresco known as the "Portrait of Sappho". ${ }^{35}$ More modest than those of Rome, the Qumrân hairnet is made of linen and corresponds to a type that is much more widespread locally and throughout the Mediterranean region. Passages from the Gospel according to Thomas, as well as the Babylonian Talmud, supplement the archaeological and iconographic data, by indicating that hairnets were worn (exclusively) by women. ${ }^{36}$ One might thus think that there were some women living in the Qumrân region.

Some textile fragments are also of major interest in the framework of this investigation. The only such fragments to have almost miraculously been preserved - although disintegrated into ashes - among the remains of the Qumrân architectural complex were found in locus 96. ${ }^{37}$ Analysis has established that they consist of linen textiles. Other linen fragments have been found in Caves 1, 8 and 11. The only wool fragments to be found (in the Christmas Cave) are decorated either with bands descending vertically from the shoulder or a gamma motif. 38

\footnotetext{
34 Berman 1999.

35 Sampaolo 1992: 104.

36 Gospel according to Thomas 41: 24; Babylonian Talmud: Shabbath 57 \& 64.

37 Bélis 2003: 251-259.

38 According to Orit Shamir and Naama Sukenik, the Christmas Cave is not associated with the Qumrân community. Shamir \& Sukenik 2011: 206 and 212.
} 
It so happens that many representations of tunics appear in the thirdcentury CE mural paintings on the walls of the synagogue of DuraEuropos in Syria, allowing one to interpret the gendered uses of these articles of clothing. The difference between the tunics worn by men, always decorated with notched bands (fig. 10), and those worn by women, decorated with the gamma pattern (fig. 9) is clearly visible. ${ }^{39}$ Apart from the fragments discovered in the Christmas Cave, other fragments featuring these two types of decoration and dating from the second century CE have been found in the Cave of Letters, located 20 $\mathrm{km}$ south of Qumrân. ${ }^{40}$ Yigal Yadin was the first to attribute these two types of decoration to different sexes. ${ }^{41}$ This interpretation was recently confirmed by Lucille Roussin, who extensively examined the question of the clothing worn by Jews. ${ }^{42}$

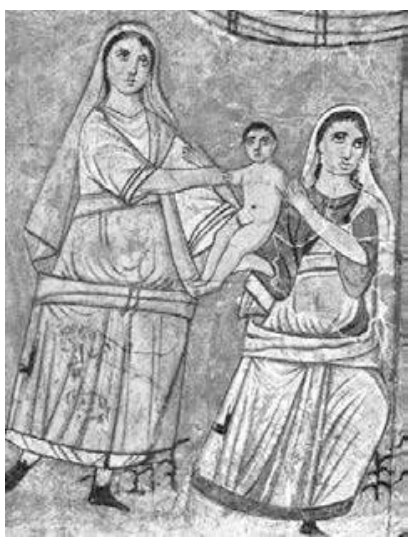

Fig. 9. Detail of the Discovery of the Infant Moses by the Egyptian Princess. Dura-Europos synagogue, third-century CE (C) Yale University Art Gallery DuraEuropos Collection.

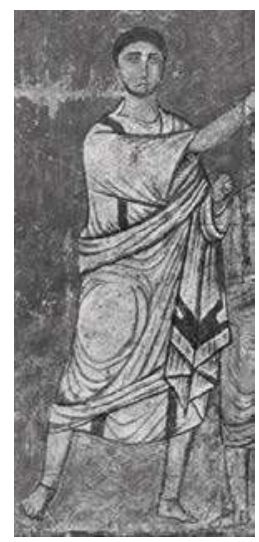

Fig. 10. Detail from the Anointing of David by Samuel 9, Dura-Europos synagogue, third-century CE (C) Yale University Art Gallery Dura-Europos Collection.

\footnotetext{
39 Roussin 2001: 184.

40 Yadin 1971: 72, 76.

41 Yadin 1971: 69-79.

42 Roussin 2001: 185-187.
} 
According to Josephus, the Essenes dressed in white (War, II, VII, Sn 5), another one of the many facts that traditionalists hoped to confirm with the archaeological discoveries. Despite the difficulty of establishing the color of the burnt fragments found in locus 96, researchers tend to underscore the correspondence between text and material culture, automatically concluding that all of the textile fragments found at Qumrân and in the region are necessarily white. Despite constant efforts to establish a link between the textile fragments and celibacy, the argument remains weak.

A final category of objects that might possibly contribute to identifying a female presence consists of perfume containers. Two types of containers associated with oils and perfumes were found in large numbers at the Qumrân site: one of them is the glass unguentarium (fusiform bottle) and the other is the ceramic flask, generally spherical in shape (fig. 11). ${ }^{43}$

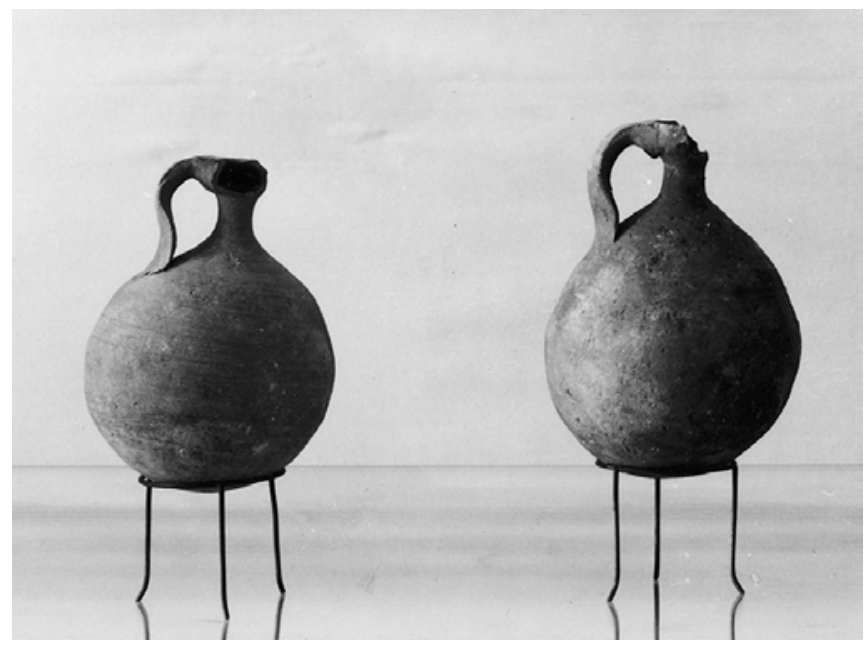

Fig. 11. Spherical jug.

Photo PAM (C) École biblique et archéologique française.

43 Donceel 1999/2000: 17. 
Biblical references indicate that perfumes contained several types of essence and herb (myrrh, aloe, cassia and cinnamon) used to embalm bodies (Isaiah, 3: 24; Song of Songs, 4: 10) or to impregnate garments (Psalms, 45: 9) and bedlinen (Proverbs, 7: 17). In contrast to modern perfumes, which consist of alcohol and distilled essences, the perfumes of antiquity were composed of mixtures of essences and oils.

The claim that only women used these perfumes doubtless reflects a preconceived idea. The texts are rather ambiguous as to the gender of their consumers. As Susan Stewart has remarked, "perfumes [during the Roman period] were worn by those who wanted to transmit a sexual message and, possibly, underscore sexual differences." 44 Achilles Tatius, a Greek writer who probably lived in the second-century BCE, had the figure of Menelaus express a veritable topos of homoerotic rhetoric when he compared the beauty of women to that of boys:

The beauty [of woman] is that of scented oils or hair-dye. If you strip her of these many deceits, she is like the jackdaw stripped of feathers, in the fable. But the beauty of boys is not watered with scents of unguents or with deceitful and alien smells; and the sweat of boys smells sweeter than all the scented unguents of women. ${ }^{45}$

Despite the censoriousness expressed in a few moralizing texts, the use of cosmetic products and perfumes was commonplace in antiquity. Several ancient authors testify to the fact that there was a harvest and production of balsam, a wild shrub that only grew in the region of the Dead Sea and was highly valued not just locally but also in distant countries. Donceel-Voûte, Patrich and Arubas, as well as Hirschfeld have associated balm [balsam] with the spherical jugs found in the region of Qumrân. ${ }^{46}$ In the New Testament and the Talmud, perfume is generally associated with women. Martial, by contrast, writes that balsam was a perfume used by some men. ${ }^{47}$ While the presence at Qumrân and its environs of these containers, generally considered to

\footnotetext{
44 Stewart 2007: 64.

45 Achilles Tatius, Leucippe and Clitophon, 2.38.2-3, Loeb Classical Library, 1969. [Here translated from the French]

46 Patrich \& Arubas 1989; Donceel-Voûte 1994: 32-33; Hirschfeld 2004: 138.

47 Martial, Epigrams, 14.59 and 3.63.4.
} 
have held essences and oils, cannot be exclusively taken as evidence of use by women, it is at the very least worth noting that the large number of them which have been found there seems in contradiction with the supposed modesty of the Essenes. ${ }^{48}$

The question of women's presence at Qumrân was addressed from the very start of research into the Dead Sea scrolls and the archaeological excavations conducted in the 1950s. However, several decades were to pass before the traditional thesis of a community of celibate men was called into question. In considerations of the issue, unfortunately, texts have always occupied the predominant role, relegating archaeological material to second place. Although most scholars today recognize that the communities described in the manuscripts included women, there is still much reluctance to accept the "ordinary" character of the site from the point of view of the sex of the inhabitants. It is true that few material traces indicate that women were present at Qumrân or in the manuscript caves. But these traces exist and the fact that there should be so few of them is not unusual when the comparison is made with other contemporary sites in the region. Although literary analysis confirms what the physical traces suggest, it is still astonishing that scholars of the texts should find it so difficult to abandon the traditional interpretation of the remains. It is to be hoped that better cooperation between philologists, archeologists and archeo-anthropologists will allow us to avoid what are now unjustifiable errors regarding the fundamental question of women's presence at Qumrân.

Translated by Ethan RUNDELL

48 Baskin 2002: 66-67; Steward 2007: 96. 


\section{Sources}

NB: Classical sources used for this article were consulted in French translation unless otherwise noted.

Flavius Josephus. La Guerre des Juifs. 1911. Translation by René Harmand, revised and annotated by Theodore Reinach. Paris: Ernest Leroux.

L'Évangile selon Thomas. 1959. Coptic text edited and translated by Antoine Guillaumont. Paris: Presses universitaires de France.

Le Talmud de Babylone. 1831. Traduit en langue française et complété par celui de Jérusalem et par d'autres monuments de l'Antiquité judaïque par l'abbé L. Chiarini, Premier Volume, Leipzig: J.A.G. Weigel.

Achilles Tatius. Leucippe and Clitophon. 1831. Text edited and translated by S. Gaselee. Cambridge, MA: Loeb Classical Library.

Martial. Epigrams, I. 1919. Edited by E. Capps, T.E. Page and W.H.D. Rouse, translated by Walter C.A. Ker, The Loeb Classical Library (London: William Heinemann \& New York: G.P. Putnam's Sons, 1919).

La Sainte Bible. 1956. Translated under the direction of the École Biblique de Jérusalem. Paris: Les Éditions du CERF.

\section{Bibliography}

ANSTETT, Élisabeth and Marie-Luce GÉLARD. 2012. Les Objets ont-ils un genre? Culture matérielle et production sociale des identités sexuées. Paris: Armand Colin.

AvNI, Gideon. 2009. Who was interred in the Qumrân Cemetery? The ethnic identity of ancient populations in the light of the archaeological findings in burial sites. Cathedra 131: 43-64 [Hebrew].

BASKIN, Judith. 2002. Midrashic Women: formations of the feminine in Rabbinic Literature. Waltham, MA: Brandeis University Press.

BÉLIS, Mireille. 2003. Révision commentée des différents systèmes de numérotation. In Khirbet Qumrân et 'Ä̈n Feshkhba. Études d'antbropologie, de physique et de cbimie, ed. Jean-Baptiste Humbert \& Jan Gunneweg, 207-276. Fribourg: Academic Press \& Göttingen: Vandenhoeck \& Ruprecht (Novum Testamentum et Orbis Antiquus, II, Series Archaeologica, 3). 
Berman, Judith. 1999. Bad hair days in the Paleolithic: modern (re)constructions of the cave man. American Anthropologist, new series 1001/2: 288-304.

CARGILL, Robert. 2009. Qumrân through (Real) Time: a virtual reconstruction of Qumrân and the Dead Sea Scrolls. Piscataway, NJ: Gorgias Press.

Clamer, Christa. 1997. Fouilles archéologiques de 'Ä̈n ez-Zâra/Callirrhoé, villégiature hérodienne. Beirut: Institut français d'archéologie du Proche-Orient.

Crawford, Sidnie White. 2003. Not according to rule: women, the Dead Sea Scrolls and Qumrân. In Emanuel: studies in the Hebrew Bible, Septuagint and Dead Sea Scrolls in honor of Emanuel Tov, ed. Shalom M. PAUl, Robert A. KRAFT, Lawrence H. SCHIFFMAN and Weston W. FIELDS, 127-150. Leiden: Brill.

Crown, Alan and Lena Cansdale. 1994. Qumrân: was it an Essene settlement? Biblical Archaeology Review 20/5: 24-35 and 73-78.

DONCEEL, Robert. 1999/2000. Antique glass from Khirbet Qumrân. Bulletin de l'Institut royal du patrimoine artistique 28: 9-40.

DonceEl-Voûte, Pauline. 1994. Les ruines de Qumrân réinterprétées. Archeologia 298: 24-35.

Eshel, Hanan, Freund, Magen Broshi Richard and Brian Schultz. 2002. New data on the cemetery east of Khirbet Qumrân. Dead Sea Discoveries 9: 135-165.

GALOR, Katharina. 2006. Gender and Qumrân. In Qumrân: a holistic view. Conference Held at Leiden University, April 2008, ed. Jan Gunneweg, Annemie AdriAens and Joris DiK, 29-38. Leiden: Brill.

GALOR, Katharina, HumberT, Jean-Baptiste and Jürgen ZANGENBERG (eds). 2010. Qumrân, the Site of the Dead Sea Scrolls: archaeological interpretations and debates. Proceedings of a Conference held at Brown University, November 17-19 2002. Leiden: Brill.

GoLB, Norman. 1995. Who Wrote the Dead Sea Scrolls? The search for the secret of Qumran. New York: Scribner.

HirschFelD, Yizhar. 2004. Qumrân in Context: reassessing the archaeological evidence. Peabody, MA: Hendrickson Publishers.

Humbert, Jean-Baptiste. 1994. L'espace sacré à Qumrân. Proposition pour l'archéologie. Revue Biblique 101: 161-214.

Humbert, Jean-Baptiste and Alain CHAmBon. 1994. Fouilles de Khirbet Qumrân et de Aïn Feshkha, I, Album de photographies, répertoire du fonds photographique, synthèse des notes de chantier du père Roland de Vaux. Fribourg: Academic Press / Göttingen: Vandenhoeck \& Ruprecht (Novum Testamentum et Orbis Antiquus, Series Archaeologica, 1).

Humbert, Jean-Baptiste and Jan Gunneweg (eds). 2003. Khirbet Qumrân et 'Aïn Feshkha, II, Études d'anthropologie, de physique et de chimie. Fribourg: Academic Press 
/ Göttingen: Vandenhoeck \& Ruprecht (Novum Testamentum et Orbis Antiquus, II, Series Archaeologica, 3).

Magen, Yitzhak and Yuval PeLEG. 2007. The Qumrân Excavations 1993-2004: preliminary report. Jerusalem: Israel Antiquities Authority (Judea and Samaria Publications - JSP, 6).

MAgness, Jodi. 2002. The Archaeology of Qumrân and the Dead Sea Scrolls. Grand Rapids, MI. Eerdmans.

Meyers, Carol. 2003. Engendering Syro-Palestinian archaeology: reasons and resources. Near Eastern Archaeology 66/4: 185-197.

NorTON, Jonathan. 2003. Reassessment of controversial studies on the cemetery. In Khirbet Qumrân et 'Ain Feshkha. Études d'anthropologie, de physique et de chimie, ed. Jean-Baptiste HumberT and Jan GunNeweg, 107-127. Fribourg: Academic Press / Göttingen, Vandenhoeck \& Ruprecht (Novum Testamentum et Orbis Antiquus, II, Series Archaeologica, 3).

Patrich, Joseph and Benny Arubas. 1989. A juglet containing balsam oil (?) from a cave near Qumrân. Israel Exploration Journal 39: 43-59.

Paul, André (ed.). 2008. La Bibliothèque de Qumrân, I. Paris: Cerf.

Politis, Konstantinos. 2006. The discovery and excavation of the Khirbet Qazone Cemetery and its significance relative to Qumrân. In Qumrân: the site of the Dead Sea Scrolls. Archaeological interpretations and debates, ed. Katharina GALOR, JeanBaptiste HumberT and Jürgen Zangenberg, 213-219. Leiden: Brill.

Rengstorf, Karl. 1960. Hirbet Qumrân und die Bibliothek vom Toten Meer. Stuttgart: Kohlhammer (transl. by J.R. Wilkie, Hirbet Qumran and the Problem of the Library of the Dead Sea Caves, Leiden: Brill, 1963 - without endnotes and indexes).

RÖHRER-ERTL, Olav. 2006. Facts and results based on skeletal remains from Qumrân found in the Collectio Kurth: a study in methodology. In Qumrân: the site of the Dead Sea Scrolls. Archaeological interpretations and debates, ed. Katharina GaLOR, Jean-Baptiste HumBERT and Jürgen ZANGENBERG, 181-194. Leiden: Brill.

ROHRHIRSCH, Ferdinand and Olav RÖHRER-ERTL. 2001. Die Individuen der Gräberfelder von Hirbet Qumrân aus der Collectio Kurth. Eine Zusammenfassung. Zeitschrift des Deutschen Palästina-Vereins 117: 164-170.

Roitman, Adolfo D., Lawrence H. SCHIFFMAN and Shani Tzoref (eds). 2011. The Dead Sea Scrolls and Contemporary Culture. Proceedings of the international conference held at the Israel Museum, Jerusalem (July 6-8, 2008). Leiden: Brill (Studies on the Texts of the Desert of Judah, 93).

Roussin, Lucille. 2001. Costume in Roman Palestine: archaeological remains and the evidence from the Mishnah. In The World of Roman Costume, ed. Judith Lynn SEBESTA and Larissa Bonfante, 182-190. Madison, WI: The University of Wisconsin Press. 
SAMPAOLO, Valeria. 1992. Immagini di donne. In Bellezza e Lusso: immagini e documenti di Piaceri della Vita: Roma, Castel Sant' Angelo, 102-132. Rome: Leonardo-De Luca.

SHAMIR, Orit and Naama SuKENIK. 2011. Qumrân textiles and the garments of Qumrân's inhabitants. Dead Sea Discoveries 18(2): 206-225.

SHERIDAN, Susan, UlLinger Jaime and Jeremy RAMP. 2003. Anthropological analysis of the human remains: the French Collection. In Khirbet Qumrân et 'Ain Feshkha : études d'anthropologie, de physique et de chimie, ed. Jean-Baptiste HUMBERT and Jan GunNeweg, 129-169. Fribourg: Academic Press / Göttingen: Vandenhoeck \& Ruprecht (Novum Testamentum et Orbis Antiquus, II, Series Archaeologica, 3).

STECKOLL, Solomon. 1968. Preliminary excavation report in the Qumrân cemetery. Revue de Qumrân 6: 323-336.

— 1969. Marginal notes on the Qumrân excavations. Revue de Qumrân 7: 33-40.

STEWART, Susan. 2007. Cosmetics and Perfumes in the Roman World. Stroud: Tempus.

VAnderkam, James and Peter Flint. 2002. The Meaning of the Dead Sea Scrolls: Their significance for understanding the Bible, Judaism, Jesus and Christianity. New York: Harper Collins.

VAux, Roland de. 1961. L'Archéologie et les manuscrits de la mer Morte. London: Oxford University Press (expanded edition of 1973, translated into English as Archaeology and the Dead Sea Scrolls, Oxford, Oxford University Press).

Whitehouse, Ruth. 2006. Gender Archaeology in Europe. In Handbook of Gender in Archaeology, ed. Sarah Milledge NeLson, 733-784. Lanham, MD: AltaMira Press.

YADIN, Yigal. 1971. Bar-Kokbba: the rediscovery of the legendary hero of the Last Jewish Revolt against Imperial Rome. London: Weidenfeld and Nicolson.

ZangenBerg, Jürgen. 2000. Bones of contention. Qumrân Chronicle 9: 51-76.

Zias, Joe. 2000. The cemeteries of Qumrân and celibacy: confusion laid to rest? Dead Sea Discoveries 7/2: 220-253. 